\title{
ODWAGA ŚWIĘTOŚCI JANA PAWŁA II
}

Jedyną rzeczą, jakiej powinniśmy żałować, jest to, że nie byliśmy święci...

(Leon Bloy)

Każdy święty Kościoła katolickiego jest inny, bo każdy ma niepowtarzalną drogę prowadzącą go do zażyłej przyjaźni z Bogiem. Takim świętym jest też Karol Wojtyła, który od wczesnego dzieciństwa był wsłuchany w słowo Boże, umiał też wyczuwać natchnienia Ducha Świętego oraz uważnie słuchać głosu własnego sumienia. Wielką pomocą w kształtowaniu jego bogatej osobowości była pełna prostoty pobożność jego rodziców. Codziennie w jego domu modlono się, dlatego Karol był niejako otulony głęboką wiarą rodziców i brata Edmunda. Już w Wadowicach zetknął się również z gorliwymi kapłanami, którzy byli dla niego wzorem w wielkodusznym oddaniu się Panu Bogu. Sam chętnie chodził do kościoła i był bardzo solidnym ministrantem.

Podczas studiów na Uniwersytecie Jagiellońskim Karol spotkał krawca z Dębnik, sługę Bożego Jana Tyranowskiego, który był przyjacielem młodzieży przy kościele Księży Salezjanów. Tak o nim wspominał papież w książce Dar i Tajemnica:

Był człowiekiem niezwykle głębokiej duchowości [...]. Od niego nauczyłem się między innymi elementarnych metod pracy nad sobą, które wyprzedziły to, co potem znalazłem w seminarium. Tyranowski, który sam kształtował się na dziełach św. Jana od Krzyża i św. Teresy od Jezusa, wprowadził mnie po raz pierwszy w te niezwykłe, jak na mój ówczesny wiek, lektury¹.

Dodajmy, że Karol nawiązał kontakt z Janem Tyranowskim w wieku około dwudziestu lat. Jego duchowy mistrz miał bardzo słabe zdrowie. W jego życiu zapisał się szczególnie dzień święceń jego rozmodlonego wychowanka, 1 listopada 1946 roku. Przebywał wtedy w szpitalu, choć tak pragnął służyć Karolowi do mszy św. prymi-

1 Jan Paweł II, Dar i Tajemnica, Kraków 1996, s. 25. 
cyjnej w krypcie św. Leonarda na Wawelu. Przez swoje cierpienie ofiarowane Panu Bogu chciał wyprosić neoprezbiterowi dar świętości i czystości serca. Jan Tyranowski zmarł 15 marca 1947 r., a obecnie toczy się jego proces beatyfikacyjny.

\section{W szkole św. Jana od Krzyża}

Dzięki pouczeniom św. Jana od Krzyża Karol potrafił z wiarą w Bożą Opatrzność przetrwać próby tragicznego okresu okupacji niemieckiej, przez które Pan Bóg go przeprowadził. Nie dziwi nas, że praca doktorska, którą ks. Karol Wojtyła napisał zaraz po zakończeniu wojny na Angelicum w Rzymie, poświęcona była właśnie kwestii wiary u św. Jana od Krzyża. Hiszpański mistyk uczył go wiary żywej, dynamicznej, szukającej i znajdującej Boga w Jego Synu, Jezusie Chrystusie. Uczył go wiary w Chrystusa w Kościele, odkrywanym pięknie stworzenia, milczącej modlitwie, ciemnościach nocy duchowej i oczyszczających płomieniach Bożej miłości. Podobnie jak dla św. Jana od Krzyża, także dla Karola ciemności, które przeżywał, stawały się paradoksalnie światłem, które prowadziło go do duchowego oświecenia i jeszcze bardziej dojrzałej wiary. To dlatego pod koniec swego życia Jan Paweł II widział w mądrości św. Jana od Krzyża inspirację do ewangelizacji współczesnego świata.

Wypełniając papieską posługę od 16 października 1978 roku, Jan Paweł II był przekonany, że do palących zadań stojących obecnie przed Kościołem należy pomoc ludziom w doświadczaniu zbawczej obecności Boga działającego w ich życiu oraz historii świata. Uważał, iż synostwo Boże i powołanie każdego człowieka do zjednoczenia z Bogiem są fundamentem jego godności. Jan Paweł II dostrzegał w św. Janie od Krzyża nowe możliwości dla odnowienia Kościoła, ażeby także przez poezję, bogactwo humanizmu oraz kulturę zakorzenioną w doświadczeniu mistycznym wychodzić do zagubionych duchowo ludzi. Lektura dzieł hiszpańskiego mistyka może pogłębić doświadczenie piękna, uczucia, zachwycenia się Stwórcą i Jego dziełem, zadziwienia tajemnicą człowieka ${ }^{2}$. Może to być ważne doświadczenie wytrącające nas z codziennej rutyny.

Jan Paweł II, sam przebywszy różne próby wiary, wołał do zebranej młodzieży na Tor Vergata w Rzymie w Jubileuszowym Roku 2000: „Wypłyńcie na głębię!”, nie bójcie się być z Bogiem sam na sam w modlitwie, także w dramatycznych momentach waszego życia. A wcześniej, w specjalnym orędziu przygotowanym z okazji Światowych Dni Młodzieży w 2000 roku, napisał do młodych całego świata, by nie bali się zostać ludźmi świętymi w nowym tysiącleciu³

2 Por. Jan Paweł II, Tryptyk rzymski, Kraków 2003.

3 Por. Jan Paweł II, Orędzie Ojca Świętego Jana Pawła II do młodych całego świata z okazji XV Światowego Dnia Młodzieży, „L'Osservatore Romano”, wyd. pol., (1999) nr 9-10, s. 18. 


\section{Spotkanie z Jezusem miłosiernym i św. Faustyną}

Kiedy młody Karol Wojtyła zamieszkał w Krakowie, szybko odkrył przesłanie św. Faustyny Kowalskiej o Bożym miłosierdziu oraz cudowny obraz Jezusa miłosiernego z kaplicy Sióstr Matki Bożej Miłosierdzia w Łagiewnikach. Uczył się tam miłości ofiarnej, odkrywając, że życie ma sens jedynie wtedy, gdy dzięki łasce Bożej czynimy z niego dar dla innych. Miłosierny Jezus był dla niego wsparciem, gdy zmarła jego matka, a później brat i ojciec. W książce Pamięć i tożsamość Jan Paweł II tak wspominał swoją duchową więź z obrazem Jezusa Miłosiernego i św. siostrą Faustyną:

Pamiętam, że podczas wojny, gdy byłem robotnikiem w fabryce „Solvay”, miejscu, które łączy się z Łagiewnikami, nieraz chodziłem do grobu siostry Faustyny, gdy jeszcze nie była ogłoszona błogosławioną. To wszystko było przedziwne, nie do przewidzenia, gdy się brało pod uwagę, że to była prosta dziewczyna. [...] Właśnie ona, parę lat przed wojną, miała to wielkie widzenie Jezusa miłosiernego, który wezwał ją, aby stała się apostołką czci dla Miłosierdzia Bożego, jaka miała potem tak szeroko się roznieść w Kościele ${ }^{4}$.

Ojciec święty podkreślał światowe wymiary kultu Bożego Miłosierdzia i nazywał św. Faustynę „wspaniałą mistyczką”. Podobnie jak ona był przekonany, że nie ma dla człowieka innego źródła nadziei, jak tylko miłosierdzie Boga. Staje się to aktualne zwłaszcza wtedy, gdy człowiek gubi się wobec wielorakich przejawów zła. Dlatego wielkim pocieszeniem dla schorowanego papieża była konsekracja bazyliki Bożego Miłosierdzia w Krakowie-Łagiewnikach dokonana 17 sierpnia 2002 roku. Był przekonany, że właśnie na tym miejscu „w ogniu Bożej miłości ludzkie serca pałać będą pragnieniem nawrócenia, a każdy, kto szuka nadziei, znajdzie ukojenie"5.

\section{Spotkanie ze świętym artystą}

Św. Karol Wojtyła przebył podobną duchową drogę jak św. Brat Albert Chmielowski: od fascynacji sztuką i doświadczenia piękna, po odkrycie piękna Jezusa jako Dobrego Pasterza. Pod koniec XIX w. Adam Chmielowski, bardzo utalentowany artysta malarz, przeżył głębokie nawrócenie, którego owocem był namalowany przez niego obraz Ecce Homo. Odtąd zaczął służyć bezdomnym Krakowa.

4 Jan Paweł II, Pamięć i tożsamość, Kraków 2005, s. 149-150.

5 Jan Paweł II, Homilia w Łagiewnikach, 17 sierpnia 2002, nr 4. 
Podobnie Karol, student polonistyki Uniwersytetu Jagiellońskiego, zafascynowany teatrem i literaturą, odkrywał jednocześnie piękno powołującego go Jezusa i postanowił zostać księdzem. Ten ofiarny gest opuszczenia wszystkiego dla Pana Boga zaowocował świętością i powszechnym dobrem Kościoła oraz całej ludzkości. Karol coraz bardziej odkrywał heroiczność posługi Adama Chmielowskiego na rzecz upośledzonych i wydziedziczonych, w których spotykał samego Jezusa. O duchowej więzi z Bratem Albertem Jan Paweł II pisał:

Bardzo byłem z nim duchowo związany [...]. Fascynowała mnie jego osobowość. Widziałem w nim model, który mi odpowiadał: rzucił sztukę, żeby stać się sługą biedaków - „opuchlaków”, jak ich nazywano. Jego dzieje bardzo mi pomogły zostawić sztukę i teatr, i wstąpić do seminarium duchownego. Codziennie odmawiam litanię narodu polskiego, w której jest św. Brat Albert ${ }^{6}$.

Owocem fascynacji Karola Wojtyły św. Adamem Chmielowskim był napisany przez późniejszego papieża dramat zatytułowany Brat naszego Boga (1945-1950).

\section{Troska o świętość rodziny}

Fundamentem świętości rodziny jest według św. Jana Pawła II oblubieńcza miłość Chrystusa do Kościoła. We wspólnocie Kościoła zostaliśmy przecież, pomimo że jesteśmy grzesznikami, powołani do świętości. Wiele razy papież z Polski odwoływał się do V rozdziału konstytucji dogmatycznej o Kościele Lumen gentium, w którym przypomina się o powszechnym powołaniu do świętości. Kościół staje się na nowo święty przede wszystkim w swoich świętych. Jan Paweł II przypominał też o powołaniu małżonków do świętości. W trosce o ich świętość głosił katechezy środowe o powołaniu kobiety i mężczyzny do wzajemnej miłości, dzięki której mogą także wejść na drogę świętości. W trosce o dobro rodziny Jan Paweł II zwołał na początku swego pontyfikatu synod o rodzinie, którego owocem jest adhortacja apostolska Familiaris consortio z 22 listopada 1981 roku. Przygotował też specjalny List do rodzin (2 lutego 1994). Pisał w nim:

Skarbiec rodziny należy w Kościele przede wszystkim do świadków, do tych wszystkich ojców i matek, synów i córek, którzy poprzez rodzinę odnaleźli drogę swego ludzkiego i chrześcijańskiego powołania - ów wymiar „wewnętrznego człowie-

6 Jan Paweł II, Wstańcie, chodźmy!, Kraków 2004, s. 150. 
ka” (Ef 3, 16), o jakim mówi Apostoł - którzy doszli do świętości. Święta Rodzina jest początkiem tylu innych świętych rodzin ${ }^{7}$.

Jan Paweł II podkreślał także fundamentalną świętość życia człowieka od poczęcia aż po naturalną śmierć ${ }^{8}$. Według kard. Carla Marii Martiniego katechezy środowe na temat małżeństwa są najbardziej oryginalnym wkładem polskiego papieża w nauczanie Kościoła. Nie dziwi nas zatem fakt, że podczas uroczystości kanonizacyjnych w Rzymie, 27 kwietnia 2014 roku, papież Franciszek ogłosił św. Jana Pawła II patronem rodzin.

Janowi Pawłowi bardzo zależało, by tworzyć w rodzinach środowiska sprzyjające dążeniu do świętości. Pytał w Starym Sączu w 1999 roku:

Co zrobić, aby dom rodzinny, szkoła, zakład pracy, biuro, wioski i miasta, w końcu cały kraj stawały się mieszkaniem ludzi świętych, którzy oddziałują dobrocią, wiernością nauce Chrystusa, świadectwem codziennego życia, sprawiając duchowy wzrost każdego człowieka? ${ }^{9}$

Ojciec święty dał nam na to pytanie odpowiedź, mówiąc, że potrzeba świadectwa odważnej wiary i pragnienia świętości, które by zagościło w każdym uczniu Jezusa.

W tej samej homilii Jan Paweł II przytoczył również fragment wspomnianego już Listu do rodzin, podkreślając, że:

poprzez rodzinę toczą się dzieje człowieka, dzieje zbawienia ludzkości. Rodzina znajduje się pośrodku tego wielkiego zmagania pomiędzy dobrem a złem, między życiem a śmiercią, między miłością a wszystkim, co jest jej przeciwieństwem. Rodzinom powierzone jest zadanie walki przede wszystkim o to, ażeby wyzwolić siły dobra, których źródło znajduje się w Chrystusie Odkupicielu człowieka, aby te siły uczynić własnością wszystkich rodzin, ażeby - jak to powiedziano w polskim millennium chrześcijaństwa - rodzina była „Bogiem silna” ${ }^{10}$.

Wielu z nas pamięta, jak bardzo zależało Janowi Pawłowi II, by polskie rodziny dochowały wierności Chrystusowi. Apelował do nas, byśmy nie pozwolili, aby w naszych sercach zgasło światło Jego świętości. Mówił ojciec święty:

7 Jan Paweł II, List do rodzin, nr 23.

8 Por. Jan Paweł II, Enc. Evangelium vitae, 1995.

9 Jan Paweł II, Pielgrzymki do Ojczyzny 1979, 1983, 1987, 1991, 1995, 1997, 1999. Przemówienia, homilie, Kraków 1999, s. 1171.

10 Jan Paweł II, List do rodzin, nr 23. 
Niech blask tego światła kształtuje przyszłe pokolenia świętych, na chwałę imienia Bożego! Tertio millennio adveniente. Bracia i siostry, nie lękajcie się chcieć świętości! Nie lękajcie się być świętymi! Uczyńcie kończący się wiek i nowe tysiąclecie erą ludzi świętych! ${ }^{11}$.

\section{Rozmodlony święty}

W 1958 roku ks. Karol Wojtyła został mianowany biskupem. Odtąd miejscem, gdzie najchętniej przebywał, była kaplica domu przy ul. Franciszkańskiej 3 w Krakowie. W książce Wstańcie, chodźmy! wyznał: „Po to kaplica jest tak blisko, żeby wszystko w życiu biskupa - nauczanie, decyzje, duszpasterstwo - zaczynało się u stóp Chrystusa utajonego w Najświętszym Sakramencie"12. W kaplicy, w przestrzeni eucharystycznej obecności Pana Jezusa, przyszły papież modlił się, przygotowywał wykłady, pisał swoje książki oraz kazania, które później wygłaszał.

Modlitwa Jana Pawła II była prosta i ufna. Wielu zauważało jego skupienie podczas Eucharystii, która była sercem jego pasterskiej posługi. Długo trwał na modlitwie dziękczynnej. Często też adorował Najświętszy Sakrament. Tak napisał w encyklice Ecclesia de Eucharistia:

Pięknie jest zatrzymać się z Nim i jak umiłowany Uczeń oprzeć głowę na Jego piersi, poczuć dotknięcie nieskończoną miłością Jego Serca. Jeżeli chrześcijaństwo ma się wyróżniać w naszych czasach przede wszystkim „sztuką modlitwy”, jak nie odczuwać odnowionej potrzeby dłuższego zatrzymania się przed Chrystusem obecnym w Najświętszym Sakramencie na duchowej rozmowie, na cichej adoracji w postawie pełnej miłości? Ileż to razy, moi drodzy Bracia i Siostry, przeżywałem to doświadczenie i otrzymałem dzięki niemu siłę, pociechę i wsparcie ${ }^{13}$.

Ojciec święty modlił się w każdą niedzielę na Anioł Pański, współuczestniczył w cierpieniu Jezusa podczas drogi krzyżowej w Wielki Piątek w rzymskim Koloseum. Odprawiał też prywatnie to nabożeństwo w każdy piątek. Łączył się duchowo z pielgrzymami zgromadzonymi na Jasnej Górze w godzinie Apelu. Był wierny modlitwie brewiarzowej i dzielił się jej duchowymi owocami podczas katechez środowych, komentując psalmy.

Troszcząc się o wszystkie Kościoły, Jan Paweł II chętnie powierzał się Bogu, który go wspierał i umacniał aż po ostatnie „fiat”, niech się stanie wola Pana,

11 Jan Paweł II, Pielgrzymki do Ojczyzny..., dz. cyt., s. 1172.

12 Jan Paweł II, Wstańcie, chodźmy!, dz. cyt., s. 115.

13 Jan Paweł II, Enc. Ecclesia de Eucharistia, nr 25. 
w pamiętny wieczór 2 kwietnia 2005 roku o godz. 21.37, gdy odchodził do domu Ojca, a mieszkańcy Rzymu i całego świata wstrzymali oddech, dziękując Bogu za tak wielki dar świętego papieża.

\section{Świętość programem Kościoła}

Według mnie niezwykle ważnym dokumentem, który wciąż może inspirować duszpasterską działalność Kościoła, jest list apostolski z 2001 roku Novo millennio ineunte. Mowa w nim jest o potrzebie wypracowania na początku nowego tysiąclecia „pedagogiki świętości”"14.

Jan Paweł II postuluje w tym dokumencie, by cała działalność duszpasterska na początku XXI wieku była wpisana w perspektywę świętości. Taki, jego zdaniem, jest trwały owoc Jubileuszu Roku 2000. Dlatego apelował, by odkryć na nowo bogactwo V rozdziału konstytucji dogmatycznej o Kościele Lumen gentium, w którym mowa jest o „powszechnym powołaniu do świętości”. Zdaniem papieża:

Wyznawać wiarę w Kościół jako święty znaczy wskazywać jego oblicze Oblubienicy Chrystusa, dla której On złożył w ofierze samego siebie właśnie po to, aby ją uświęcić (por. Ef 5, 25-26). Ten dar świętości - by tak rzec - obiektywnej - zostaje ofiarowany każdemu ochrzczonemu. Dar jednak z kolei sam staje się zadaniem, któremu winno być podporządkowane całe życie chrześcijanina: „Albowiem wolą Bożą jest wasze uświęcenie” (1 Tes 4,3). To zadanie nie dotyczy tylko niektórych chrześcijan: „wszyscy chrześcijanie jakiegokolwiek stanu i zawodu powołani są do pełni życia chrześcijańskiego i do doskonałości miłości”15.

\section{Czy chcesz zostać świętym?}

Jan Paweł zastanawiał się, czy można zaprogramować świętość. I odpowiadał tak:

Zadać katechumenowi pytanie: „Czy chcesz przyjąć chrzest? ” znaczy zapytać go zarazem: „Czy chcesz zostać świętym? ”. Znaczy postawić na jego drodze radykalizm Kazania na Górze: „Bądźcie więc wy doskonali, jak doskonały jest Ojciec wasz niebieski” (Mt 5, 48). [...] Drogi świętości są wielorakie i dostosowane do każdego powoła-

14 Por. Jan Paweł II, List apost. Novo millennio ineunte, 6 stycznia 2001 [dalej: NMI], nry 30-31.

15 NMI 30. 
nia. Składam dzięki Bogu za to, że pozwolił mi beatyfikować i kanonizować w minionych latach tak wielu chrześcijan, a wśród nich licznych wiernych świeckich, którzy uświęcili się w najzwyklejszych okolicznościach życia. Dzisiaj trzeba na nowo z przekonaniem zalecać wszystkim dążenie do tej „wysokiej miary” zwyczajnego życia chrześcijańskiego. Całe życie kościelnej wspólnoty i chrześcijańskich rodzin winno zmierzać w tym kierunku. Ale jest też oczywiste, że istnieją różne indywidualne drogi do świętości, wymagające prawdziwej pedagogiki świętości, która zdolna jest dostosować się do rytmu poszczególnych osób ${ }^{16}$.

Kiedy spotykamy na naszej drodze świętych, przeczuwamy także w swoim sercu niewypowiedzianą tajemnicę Boga. Doniosłość i znaczenie spotkania z człowiekiem świętym tak opisał francuski jezuita, przyjaciel Jana Pawła II, kard. Henri de Lubac:

Objawia się nam nagle nowe życie, strefa nowego istnienia $\mathrm{z}$ całą głębią nie tylko niespodziewaną, ale nawet dźwięczącą obco i dziwnie. Coś jakby nowa „ojczyzna”, początkowo nieznana, ale zaraz potem odbierana jako najdawniejsza i najprawdziwsza ojczyzna, jakiej zawsze serce pragnęło ${ }^{17}$.

Także nasze spotkanie ze św. Janem Pawłem, choćby przez lekturę jego dzieł, medytację jego homilii czy przekazaną żywą tradycję, może być dla nas wezwaniem do nawrócenia i podjęcia decyzji, by z większą niż dotąd gorliwością szukać Boga i budować Jego królestwo w świecie.

\section{Święci zawstydzają}

Jan Paweł II w 1987 roku, podczas beatyfikacji bł. Karoliny Kózkówny, męczennicy z czasów I wojny światowej, tak mówił do wiernych w Tarnowie:

Czyż święci są po to, ażeby zawstydzać? Tak. Mogą być i po to. Czasem konieczny jest taki zbawczy wstyd, ażeby zobaczyć człowieka w całej prawdzie. Potrzebny jest, ażeby odkryć lub odkryć na nowo właściwą hierarchię wartości. Potrzebny jest nam wszystkim, starym i młodym. Chociaż ta młodziutka córka Kościoła tarnowskiego, którą od dzisiaj będziemy zwać błogosławioną, swoim życiem i śmiercią mówi przede wszystkim do młodych. Do chłopców i dziewcząt. Do mężczyzn i kobiet. Mówi o wielkiej godności kobiety: o godności ludzkiej osoby. O godności ciała, któ-

16 NMI 31.

17 H. de Lubac, Na drogach Bożych, tłum. A. Turowiczowa, Paris 1970, s. 136. 
re wprawdzie na tym świecie podlega śmierci, jest zniszczalne, jak i jej młode ciało uległo śmierci ze strony zabójcy, ale nosi w sobie to ludzkie ciało zapis nieśmiertelności, jaką człowiek ma osiągnąć w Bogu wiecznym i żywym, osiągnąć przez Chrystusa.Tak więc święci są po to, ażeby świadczyć o wielkiej godności człowieka. Świadczyć o Chrystusie ukrzyżowanym i zmartwychwstałym „dla nas i dla naszego zbawienia”, to znaczy równocześnie świadczyć o tej godności, jaką człowiek ma wobec Boga. Świadczyć o tym powołaniu, jakie człowiek ma w Chrystusie ${ }^{18}$.

Męczeńska śmierć Karoliny Kózki jest jeszcze jednym potwierdzeniem, że, jak napisał kard. Henri de Lubac:

Najlepsi i najbardziej aktywni chrześcijanie nie muszą wcale rekrutować się spośród uczonych lub ludzi szczególnie uzdolnionych; spośród intelektualistów, polityków czy „społecznych autorytetów”. W konsekwencji ich głos nie rozbrzmiewa w gazetach, a ich czyny nie zajmują opinii publicznej. Żyją ukryci przed oczyma świata [...]. To jednak właśnie oni, bardziej niż wszyscy inni, przyczyniają się do tego, że nasza ziemia nie staje się piekłem ${ }^{19}$.

Święci, zwłaszcza męczennicy, budzą sumienia! Właśnie dlatego Jan Paweł II pragnął wzniecić wśród misjonarzy i w całym Kościele nowy „zapał świętości”. Zwracał się przede wszystkim do młodych, by promieniowali entuzjazmem i odwagą w wielkodusznym oddaniu się Bogu i bliźniemu ${ }^{20}$. To święci męczennicy świadczą o miłości Boga do każdego człowieka i bronią go przed nim samym, zwłaszcza wtedy, gdy chce budować swoje życie daleko od Chrystusa i Jego Kościoła. Każdy święty jest „znakiem sprzeciwu” wobec tego wszystkiego, co niszczy godność człowieka powołanego do przyjaźni z Bogiem. Przez swoje ewangeliczne życie święci stają się wezwaniem do naszego nawrócenia ${ }^{21}$.

\section{Benedykt XVI o świętości Jana Pawła II}

W jednym z wywiadów przed kanonizacją Jana Pawła II papież Benedykt XVI powiedział, że w ciągu lat współpracy z polskim papieżem stawało się dla niego coraz bardziej jasne, że był on człowiekiem świętym. Na co dzień dostrzegał jego intensywną relację z Bogiem i jego zanurzenie w komunii z Panem. Mówił:

18 Jan Paweł II, Homilia w czasie Mszy św. beatyfikacyjnej Karoliny Kózkówny, Tarnów, 10 czerwca 1987, nr 3.

19 H. de Lubac, Medytacje o Kościele, tłum. I. Białkowska-Cichoń, Kraków 1997, s. 247.

20 Por. Jan Paweł II, Enc. Redemptoris missio (1990), nry 90-91.

21 Por. H. de Lubac, Paradoxe et mystère de L'Église, Paris 1967, s. 213-222. 
Tu było źródło jego radości, którą promieniował w najcięższych doznawanych trudach, oraz odwaga, z jaką pełnił swe zadanie w naprawdę ciężkim czasie. Jan Paweł II nie szukał poklasku i nie rozglądał się dokoła, jak są przyjmowane jego decyzje. W swym działaniu opierał się na wierze i na swych przemyśleniach, i gotów był przyjmować na siebie także różne ciosy. W moim przekonaniu, odwaga kierowania się prawdą stanowi pierwszoplanowe kryterium świętości ${ }^{22}$.

\section{Spotkanie ze świętym przemienia}

Kiedy stykamy się z takimi ludźmi, jak św. Jan Paweł II, wtedy budzi się w nas to, co najpiękniejsze. Na nowo odżywa w nas tęsknota za Panem Bogiem i odradza się pragnienie świętości. W takich chwilach doświadczamy życia w harmonii i wewnętrznego pokoju. Nasze życie nabiera głębokiego sensu i jest bardziej scalone. Ojciec święty często przypominał, że pokój serca i brak lęku jest możliwy tylko wtedy, gdy całe nasze życie zakorzenione jest w Panu Bogu. Gdy budowane jest na Chrystusowej skale, a nie na piaskach złudnych ideologii opartych na humanistycznym ateizmie.

Zastanawiając się nad tajemnicą świętości życia Jana Pawła II, możemy odkryć, że Pan Bóg prowadził go na każdym etapie ziemskiej wędrówki. Pytamy czasem, czego uczy nas dzisiaj św. Jan Paweł II. Jakie rady i wskazówki, a przede wszystkim, które spośród jego postaw mogą być w naszych czasach - zwłaszcza dla ludzi młodych - inspiracją do podjęcia nowych zadań związanych z naszym zawodem czy powołaniem? W jaki sposób jego przykład może rozjaśnić różne sytuacje w naszym życiu?

\section{Świętość wypróbowana przez cierpienie}

Św. Jan Paweł II uczy nas cierpliwego znoszenia choroby i cierpienia. Sam był człowiekiem bardzo wrażliwym, ktoś nawet stwierdził, że jest on ostatnim polskim romantykiem. W liście apostolskim Salvifici doloris napisał o „Ewangelii cierpienia”. Przypomniał, że jeśli człowiek przeżywa swoje cierpienie z Chrystusem, to wówczas staje się ono Dobrą Nowiną i tylko wtedy jest to cierpienie twórcze. Tylko tak przeżywane cierpienie nie niszczy człowieka, stając się okazją do duchowego pogłębienia.

Ojciec święty uczył nas też, jak otwierać się na nowe przestrzenie ducha, które są w naszym sercu. Kiedy człowiek podejmuje trudną drogę, o której pisze

22 Por. „Niedziela” (2014) nr 11, s. 10. 
św.Jan od Krzyża w Drodze na górę Karmel, to jest to zawsze wąska droga krzyża, po której wspinał się w górę również św. Jan Paweł II. On miał świadomość, że na każdym etapie swego życia wspomagany był przez Pana Boga. W tej owocującej współpracy z Bożą łaską jest dla nas jaśniejącym wzorem.

\section{Przywracał nadzieję}

Św. Jan Paweł II przekazał całemu Kościołowi, a także ludziom niewierzącym, umiejętność życia nadzieją. Ufając Bogu, patrzył również z wielką ufnością na losy świata. Fundamentem jego życia była wiara w Jezusa zmartwychwstałego, Pana całej historii. Z modlitw Jana Pawła II do Matki Bożej przebija Duch pocieszenia. Podczas audiencji środowych papież często zwracał się do Maryi, wypraszając dla Kościoła dar odwagi. Czynił to zwłaszcza po 13 grudnia 1981 roku, w czasie stanu wojennego w Polsce. Modlił się wtedy, abyśmy byli mocni wiarą, potrafili wzmacniać w sobie „wewnętrznego człowieka”, który jest dzieckiem Boga. Takiemu człowiekowi nie może zabraknąć nadziei. Pozostawił nam też święty papież świadectwo, w którym czytamy:

Oto już dzisiaj Panie, kiedy mogę jeszcze samodzielnie się poruszać i jestem w pełni moich władz umysłowych, już zawczasu deklaruję przed Tobą przyjęcie przeze mnie Twojej świętej woli. I jeśli taka lub inna spośród tych prób miałaby dotknąć i mnie, to pragnę, aby służyła Twojej chwale i zbawieniu ludzkości. Od tej chwili proszę Cię, byś z Twoją łaską był pomocą dla tych, którzy będą mieli niewdzięczne zadanie pielęgnowania mnie. Jeżeli pewnego dnia stanie się, że choroba dotknie mojego umysłu i zaciemni rozum, to już teraz poddaję się Tobie tym poddaniem, które potem zyska swoją kontynuację w milczącej adoracji. Gdybym pewnego dnia miał się położyć na długo, pozostając bez świadomości, to pragnę, aby każda godzina, którą będzie mi dane w taki sposób przeżyć, była nieprzerwanym dziękczynieniem, a moje ostatnie tchnienie było także tchnieniem miłości. Wówczas, w takiej chwili, moja dusza prowadzona ręką Maryi stanie przed Tobą, aby na wieki wyśpiewywać Twoją chwałę. Amen. ${ }^{23}$

O tym, że Jan Paweł II wypełnił swój Testament, świadczą słowa papieża Benedykta XVI:

23 Cyt. za: http://jmichalik.episkopat.pl/wypowiedzi/4151.0,Modlitwa_Jana_Pawla_II.prn 
Ze wzruszeniem patrzyłem na jego [Jana Pawła] cierpienie, widziałem także jego zjednoczenie z cierpiącym Panem i to, że swoje cierpienie znosił z Chrystusem i dla Chrystusa, a jednocześnie był w pełni świadomy i promieniował wewnętrzną pogodą. Gdy spotkałem się z nim po raz drugi, na dzień przed śmiercią, papież cierpiał jeszcze bardziej, to było widoczne. Otaczali go lekarze i przyjaciele; wciąż był świadomy. Pobłogosławił mnie. Nie mógł już za bardzo mówić, ale dla mnie ta jego cierpliwość w cierpieniu była - powiedziałbym - wielką lekcją. Przede wszystkim jednak czułem, widziałem, że jest w rękach Boga: poddawał się Jego woli i dlatego, mimo widocznego bólu, zachowywał spokój, gdyż był w ręku Bożej Miłości ${ }^{24}$.

\section{Abstract}

\section{The courage of the Karol Wojtyła's holiness}

Every saint Catholic Church differs from others, because every one of them has their own and unique path to close friedship with God. Karol Wojtyla was also such a saint. Since his early childhood he has been paying a great attention to the Word of God, moreover, he could sense inspirations given to him by the Holy Spirit, and above all, he listened to the voice of his own conscience. His rich personality was shaped by the staightforwardness of his parents' godliness. In the Wojtyla's house a prayer was present every day and because of that, Karol was immersed in a deep faith of his parents and his brother Edmund.

Karol Wojtyla mastered the courage of the holiness in the spiritual school of the St John of the Cross, St. Brother Albert Chmielowski and St. Faustyna Kowalska. He alone experienced great love from his parents and this very fact inspired him to look after the holiness of all families across the globe. A calling for sainthood, in the whole Church, was a leading program of John Paul II pontificate. His incessant devotion toward unity with God has became tested by his sufferings which renewed hope for all those men and women who became lost in the modern world.

Marek Wójtowicz SJ, Odwaga świętości Jana Pawła II, [w:] Twarze świętości, red. Katarzyna Dybeł, Zofia Zarębianka, Kraków 2016, s. 59-70 (Dni Jana Pawła II).

http://dx.doi.org/10.15633/9788374385503.07

24 Benedykt XVI, Człowiek, który żył Bogiem. Rozmowa z Benedyktem XVI z okazji Dnia Papieskiego, „L'Osservatore Romano”, wyd. pol., (2005) nr 11-12, s. 42. 